\title{
Expression of Z01, vimentin, pan-cadherin and AGTR1 in tanycyte-like cells of the sulcus medianus organum
}

DOI:

10.1016/j.bbrc.2018.05.151

\section{Document Version}

Accepted author manuscript

Link to publication record in Manchester Research Explorer

\section{Citation for published version (APA):}

Al-kaabi, M., Hussam, F., Al-marsoummi, S., Al-anbaki, A., Al-salihi, A., \& Al-aubaidy, H. (2018). Expression of ZO1, vimentin, pan-cadherin and AGTR1 in tanycyte-like cells of the sulcus medianus organum. Biochemical and Biophysical Research Communications, 502(2), 243-249. https://doi.org/10.1016/j.bbrc.2018.05.151

\section{Published in:}

Biochemical and Biophysical Research Communications

\section{Citing this paper}

Please note that where the full-text provided on Manchester Research Explorer is the Author Accepted Manuscript or Proof version this may differ from the final Published version. If citing, it is advised that you check and use the publisher's definitive version.

\section{General rights}

Copyright and moral rights for the publications made accessible in the Research Explorer are retained by the authors and/or other copyright owners and it is a condition of accessing publications that users recognise and abide by the legal requirements associated with these rights.

\section{Takedown policy}

If you believe that this document breaches copyright please refer to the University of Manchester's Takedown Procedures [http://man.ac.uk/04Y6Bo] or contact uml.scholarlycommunications@manchester.ac.uk providing relevant details, so we can investigate your claim.

\section{OPEN ACCESS}




\title{
Expression of Z01, Vimentin, Pan-cadherin and AGTR1 in Tanycyte-Like Cells of the Sulcus Medianus Organum
}

\author{
Muthanna Al-Kaabia,b, Fadhil Hussam ${ }^{a}$, Sarmad Al-Marsoummi,c, Ali Al-Anbakid , Anam Al-Salihia , \\ and Hayder Al-Aubaidye \\ a Al-Nahrain University, College of Medicine, Department of Human Anatomy, Baghdad, Iraq. \\ $b$ University of Tasmania, Faculty of Health, School of Medicine, Medical Science Precinct, Hobart, \\ Tasmania, Australia. \\ c University of North Dakota, School of Medicine and Health Sciences, Department of Biomedical \\ Sciences, North Dakota, USA \\ d University of Manchester, Faculty of Biology, Medicine and Health, Manchester, UK \\ e La Trobe University, School of Life Sciences, Bundoora, VIC, 3083, Australia
}

\section{Corresponding Author}

Hayder Al-Aubaidy

Senior Lecturer

School of Life Sciences, La Trobe University

Bundoora, VIC, 3083, Australia

Tel: $+61(0) 362266975$

Email: h.alaubaidy@utas.edu.au

\section{Ethical statement}

The guidelines for the care and use of experimental animals were performed in accordance with the regulations of the University of Tasmania Animal Ethics Committee - Project A0014584.

\section{Conflict of interest}

The authors declare that they have no conflict of interest.

\section{All authors have approved the final article}




\section{Author contributions}

Muthanna Al-Kaabi: conceptualization, investigation, methodology, curation, validation and visualization of data, supervision, manuscript writing (original draft, review and editing), project administration; Fadhil Hussam: collection and assembly of data; Sarmad Al-Marsoummi: conception and design, manuscript writing (critical review); Ali Al-Anbaki: manuscript writing (critical review); Anam Al-Salihi: conception and design; Hayder Al-Aubaidy: interpretation of data, management and supervision.

\section{Funding}

This work was supported by a grant from the Australian Endeavour Postdoctoral Fellowships (grant number 3774_2014)

\section{Abbreviations}

AP: Area Postrema; CVOs: Circumventricular Organs; ME: Median Eminence; SMO: Sulcus Medianus Organum 


\section{$\underline{\text { Abstract }}$}

Tanycytes are a specialized ependymal lining of brain ventricles with exceptional features of having long basal processes and junctional complexes between cell bodies. These tanycytes are present at the regions of circumventricular organs (CVOs) which possess common morphological and functional features enabling them to be described as the brain windows where the barrier systems have special properties. Previous studies detailed seven of these CVOs but little information is available regarding another putative site at the rostral part of the median sulcus of the $4^{\text {th }}$ ventricle, or the sulcus medianus organum (SMO). Here we performed a pilot immunohistochemical study to support earlier observations suggesting the SMO as a novel CVO. We labeled rat brain with ZO1, vimentin, pancadherin and angiotensin II type 1 receptors markers which showed a morphologically distinct population of cells at the region of the SMO similar to tanycytes present in the median eminence, a known CVO. These cells had basal processes reaching the deeply seated blood vessels while the caudal part of the median sulcus did not show similar long cellular extensions. We concluded that tanycyte-like cells are present in the SMO in a pattern resembling that of other CVOs where the strategic location of the SMO is probably for signal integration between brainstem nuclei and the rostrally located neuronal centers.

\section{Highlights}

- SMO contains ependyma with distinct tanycyte-like population

- These cells express ZO1, vimentin, pan-cadherin and angiotensin II type 1 receptors

- Long basal processes bridge these tanycyte-like cells to deeper blood vessels

\section{Keywords}

Tanycytes; circumventricular organs; sulcus medianus organum; immunohistochemistry 


\section{Introduction}

Circumventricular organs (CVOs), refer to small structures bordering the ventricular spaces in the midline of the brain which share common morphological and endocrine-like characteristics that distinguish them from the rest of the nervous system. These specialized areas are points of communication between the blood, the brain parenchyma, and the CSF (Benarroch, 2011). Among their unique features are cellular contacts with two fluid phases (blood and cerebrospinal fluid) and neural connections with strategic brain nuclei establishing circuitry for communications throughout the neuraxis (Johnson and Gross, 1993). Various additional morphological and functional features implicate CVOs in a wide array of homeostatic processes; CVOs are believed to form part of a dynamic body of possibly interrelated epithelial cells within the ventricular system of the brain (Collins, 1989). Most of them develop in close apposition to rich, fenestrated capillary networks. They share a common ontogeny, being differentiated from and remaining within the ependymal layer of the neural tube (Joly et al., 2007). Topographically, they are found in the midline either in the recesses or they cover the commissures within the ventricular system. CVOs are characterized by their extensive vasculature and lack of the usual blood brain barrier (BBB) (Collins, 1989). There are seven known CVOs, namely, the median eminence (ME) (Ganong, 2000), neurohypophysis, vascular organ of the lamina terminalis, subfornical organ, pineal gland, subcommissural organ and area postrema (AP) (Duvernoy and Risold, 2007).

The BBB is present throughout the central nervous system except for the CVOs located around the third and fourth cerebral ventricles, in addition to the choroid plexuses. Thus, CVOs are in persistent contact with signaling molecules circulating in the bloodstream. Neurons at the CVOs have a variety of receptors for hormones and other signaling molecules, and they have extensive connections to hypothalamic and brainstem nuclei. Therefore, lying at the blood-brain interface, the sensory CVOs are in a unique position of being able to detect and integrate humoral and neural information and relay the resulting signals to autonomic control centers of the hypothalamus and medulla (Fry and Ferguson, 2007). They have a proven role in the control of cardiovascular function and body fluid regulation, and have significant involvement in central immune response, feeding behavior and reproduction (Cottrell and Ferguson, 2004). In that aspect, tanycytes, a unique cell population present in the lining of the third and fourth ventricles, may bridge the gap between the central nervous system via cerebrospinal fluid (CSF) to the portal blood. This may also link the CSF to neuroendocrine events (Langlet et al., 2013, Mullier et al., 2010). These tanycytes are highly specialized ependymoglial cells that form a blood-CSF barrier at the level of the CVOs; such a barrier has well documented properties through the presence of tight junctions at the ventricular pole of tanycytes (Langlet, 2014).

Of the four subtypes of tanycytes ( $\alpha 1, \alpha 2, \beta 1$ and $\beta 2$ ) only $\beta 2$ tanycytes are apically joined by tight junctions in the floor of the third ventricle (Rodriguez et al., 2005, Rizzoti and Lovell-Badge, 2016). Tanycytes, which are considered as specialized ependymal cells (ECs) connected by tight junctions, form a complex network that seal the CNS from the CVOs, creating a distinct blood-CSF 
barrier. This barrier is detected in the floor and walls of the third ventricle (Langlet et al., 2013, Mirzadeh et al., 2017, Mullier et al., 2010) as well as in the floor of the fourth ventricle (Collins, 1989).

This displacement of the barrier properties from the vascular to the ventricular side allows the diffusion of blood-borne molecules into the parenchyma of the CVOs, while tanycyte tight junctions control their diffusion into the CSF, thus maintaining brain homeostasis (Langlet et al., 2013) (figure 1). In addition to tight junctions, tanycytes demonstrate the presence of adhesion junctions at the ventricular cell pole, cell body, basal process, and terminal ending (Rodriguez et al., 2005).

In the fourth ventricle, only the AP has been identified as a CVO (Morita and Miyata, 2012) that is capable of detecting circulating signals of osmotic, cardiovascular, immune and metabolic status (Hindmarch et al., 2011). The presence of AT1a and AT1b angiotensin II receptors mediating the central response to circulating angiotensin II has been recently confirmed in the AP (Premer et al., 2013). Angiotensin II has multiple roles in the brain such as stimulation of drinking, increased salt appetite, elevation of blood pressure (Mendelsohn et al., 1984), and the regulation of the autonomic, hormonal and behavioral response to stress (Bregonzio et al., 2008, Walimbe et al., 2003). Some specific angiotensin II AT1-receptor antagonist may lower blood pressure, at least in part, by central noradrenergic inhibition (Campese et al., 2000). This inhibition is believed to be mediated by blocking AT1 angiotensin II receptors found in various regions of the brain including CVOs which are involved in the regulation of blood pressure (Macova et al., 2009, Bregonzio et al., 2008).

At present, few studies explored whether the rostral part of the median sulcus of the fourth ventricle or the sulcus medianus organum (SMO) is another CVO. The ependymal epithelium of this region is pseudostratified; the cells possess narrow necks and long basal processes that either reach deep into the neuropil or end adjacent to blood vessels. The apical surface of these ependyma has microvilli but only a few cilial clumps are present where supraependymal cells are commonly seen. A characteristic feature of this region is the presence of tight junctions just beneath the apical surface of the cells (Collins, 1989). In another study, tanycyte shafts in the midline floor of the fourth ventricle were suggested to transduce fourth ventricular CSF-borne influences to neurons of the midline medullary raphe bundle through communication channels (Cummings and Felten, 1979). Investigations done with electron microscope showed pinocytotic vesicles between the microvilli on the cell surface with complex interdigitations on the lateral walls of ECs including electron-dense desmosomes and tight junctions. Numerous free cytoplasmic ribosomes are present in each cell which possesses a thin basal process that has desmosome-like contacts with other cell processes (Collins, 1989, Lindemann and Leonhardt, 1973).

This study aims for investigating the possible localization of tanycyte-like cells in the floor of the fourth ventricle through the identification of the morphological and structural features of specialized ECs at the region of the SMO. 


\section{Materials and Methods}

\section{Sample collection and Tissue preparation}

Ten adult male Sprague Dawley rats (Rattus norvegicus albinus), aged 3 months with body weight of 250-350 g from the Cambridge Farm Facility in Tasmania (Australia) were used in this study during January 2015. Animals were kept for 2 weeks in the standard caging procedures. At the day of experiment, animals were euthanized in $\mathrm{CO}_{2}$ box and their brains were dissected out and fixed immediately in $10 \%$ neutral buffered formalin for 48 hours. Specimens of the desired regions (figure 2) (Roth et al., 2004) were carefully trimmed and processed in Leica ASP200S Autoprocessor (Kumar and Rudbeck, 2009). Paraffin blocks were prepared with LAMB-RA Embedding Centre. Serial $5 \mu \mathrm{m}$ sections were cut, mounted on Dako FLEX IHC positively charged microscope slides (Code K8020) and made ready for the next procedures.

\section{Immunohistochemistry}

Slides were dewaxed twice in xylene (Merck, Batch no. 45261) for 5 minutes with 10 seconds agitation halfway, once in 100\%, 95\%, 70\% ethanol (Fronine Laboratory Supplies) for 3 minutes each with 10-20 seconds agitation, then 3 minutes in running tap water. Antigen retrieval was done with (Target Retrieval Solution Ready-to-Use, pH 6, Dako, Code S1700) in an electric pressure cooker (Russell Hobbs) for 20 minutes. Slides were left to cool for 20 minutes at room temperature and finally washed with running water for 20 minutes.

The slides were loaded onto the racks of Dako Autostainer Plus machine for labeling with antibodies which were diluted with Dako Envision ${ }^{\text {TM }}$ FLEX antibody diluent (Dako, Code DM830). Sections were co-labeled with anti-vimentin (rabbit polyclonal, 1/400) and anti-pan cadherin (mouse monoclonal, 1/800) primary antibodies for 120 minutes at room temperature. Sections then received three 15 minutes washes in Tris-buffered saline (TBS), pH 7.6 (Dako, Code S1968), followed by incubation for 60 minutes at room temperature with the secondary antibodies: $C^{\mathrm{TM}} 647$ conjugated goat anti-rabbit IgG (1/400, for vimentin labeling) and $\mathrm{CF}^{\mathrm{TM}} 488 \mathrm{~A}$ conjugated goat anti-mouse IgG (1/400, for pan cadherin labeling) diluted in the Dako Envision ${ }^{\mathrm{TM}}$ FLEX antibody diluent. Sections then were washed three times in TBS each one for 15 minutes.

Vimentin and pan cadherin co-labeled sections were then processed for sequential labeling with anti-AGTR1 primary antibodies (rabbit polyclonal, 1/400) for 120 minutes at room temperature. Sections then received three 15 minutes washes in TBS, followed by incubation for 60 minutes at room temperature with the secondary antibodies: $\mathrm{CF}^{\mathrm{TM}} 555$ conjugated goat anti-rabbit IgG (1/400, for AGTR1 labeling), followed by three times washing in TBS for 15 minutes each. After the staining process completed, slides were mounted in Fluoroshield with DAPI (Sigma, Code F6057). Stained slides were stored in the dark at $4^{\circ} \mathrm{C}$ for subsequent confocal microscope examination.

Raw sections prepared at the University of Tasmania were transferred with the necessary ingredients to Al-Nahrain University College of Medicine facility (Iraq). These sections were stained with hematoxylin and eosin stain (Bancroft, 2013), in addition to labeling with anti-ZO1 antibodies. 
Hydrated slides were processed for antigen retrieval. Slide were put in Coplin jars containing sodium citrate buffer (BDH AnalaR ${ }^{\circledR}$ ) (Shi et al., 2007). These jars were then put in an autoclave $\left(120^{\circ} \mathrm{C}, 1.2\right.$ Bar) for 30 minutes and left to cool down to room temperature for 20 minutes. Slides were washed in running tap water for 5 minutes, distilled water for 5 minutes, TBS-Tween 20 (BDH AnalaR $\left.{ }^{\circledR}\right)$ for 5 minutes and finally rinsed 3 time with TBS.

Tissue sections were then "ringed" using a wax pen and incubated in a humid chamber for 120 minutes at room temperature $\left(25^{\circ} \mathrm{C}\right)$ with anti-ZO1 primary antibodies (rabbit polyclonal, $1 / 100$ ) directly conjugated with FITC and diluted in TBS. Mounting and storage were performed as previously stated.

Background staining and antibody optimization were managed by titrating the antibody in double dilutions (i.e. 1:50, 1:100, 1:200 and so forth) and choosing the lowest dilution that gives strong specific labeling with the lowest background staining (optimal signal:noise ratio).

Examination of slides stained with hematoxylin and eosin was done using Polivar light microscope (Richert-Jung ${ }^{\circledR}$ ) and photographed with Nikon D3000 ${ }^{\circledR}$ digital camera.

Those slides labelled with (anti-ZO1-FITC) were examined with Axio fluorescent microscope (ZEISS ${ }^{\circledR}$ ). Two UV filters were used: $519 \mathrm{~nm}$ FITC filter (bright green), and $435 \mathrm{~nm}$ DAPI filter (blue).

\section{Controls}

Negative controls were prepared by staining serial sections in two different methods. First, slides were processed through the same staining procedure except for the substitution of the primary antibodies with either normal rabbit serum (for sections labeled with ZO1, vimentin and AGTR1) or with normal mouse serum (for those labeled with pan-cadherin). Second, serial sections were stained with a single primary-secondary antibody combination to confirm that each primary antibody recognizes its specific antigen. Positive controls were prepared from kidney sections to show each antibody labeling.

\section{Confocal microscopy}

Slides were studied with a Nikon Eclipse Ti confocal laser microscope set up with the laser outputs as follows: $405 \mathrm{~nm}$ (40\%) window 60, $488 \mathrm{~nm}$ (40\%) window 60, $561 \mathrm{~nm}$ (30\%) window 50 and $640 \mathrm{~nm}$ $(30 \%)$ window 70 . Images were taken in the $x-y$ single plane mode for each fluorophore using $x 10$, x20 and x40 dry lenses (Nikon PlanFluor) for subsequent analysis with ImageJ 1.48v software.

\section{Results}




\section{Hematoxylin and Eosin}

The ventricular wall of the ME had a single-layer lining of ECs (figure 3). The median sulcus at the region of the SMO was seen as a longitudinal cleft in the floor of the $4^{\text {th }}$ ventricle, with the banks lined by a single layer of ECs while the depth had a lining of more than one cell layer (figure 4).

\section{Immunohistochemistry}

\section{$Z 01$}

The ependymal lining of brain ventricles at the regions of ME and SMO had ZO1 immunohistochemical reactivity validated with internal and external controls (figure 5).

\section{Vimentin}

Ependymal lining in the $4^{\text {th }}$ ventricle walls and the SMO region were vimentin-positive. Midline ECS showed long basal processes extending deeply into the medullary parenchyma, in contrast to ECs at the dorsal ventricular wall which did not show similar extensions (figure 6). The ependymal lining of the caudal part of the $4^{\text {th }}$ ventricle median sulcus showed much shorter vimentin-labeled processes compared to those seen in the SMO region (figure 7). In figure 8, vimentin-labeled ECs basal processes were observed in the lining of the $3^{\text {rd }}$ ventricle at the region of the ME extending towards the deeper capillaries. Similarly, vimentin-labeled processes extended from ECs at the $4^{\text {th }}$ ventricle surface into the region of the AP.

\section{Pan-cadherin}

Pan-cadherin labeling of the ECs in the $3^{\text {rd }}$ and $4^{\text {th }}$ ventricles showed a honeycomb pattern of adhesion junctions at the ventricular cell surface (figures 6, 7 and 8). Similar to vimentin, pancadherin immunoreactivity also extended along the basal processes of ECs to the deeper parenchyma.

\section{AGTR1}

Immune reactivity of AGTR1 was observed at the ependyma of the $3^{\text {rd }}$ and $4^{\text {th }}$ ventricles as well as at the region of the SMO, caudal part of the median sulcus, ME and AP. In addition, AGTR1 labeling was demonstrated at the basal processes of these cells. The labeling was also seen in many cells of the cerebrum, cerebellum, and brainstem and in the deeply seated blood vessels; however, it showed weak labeling intensity at ECs of the dorsal aspect of the $4^{\text {th }}$ ventricle (figure 6 ).

Images of the SMO showed more labeling of parenchymal cells with AGTR1 in contrast to those in the caudal part of the median sulcus. The AGTR1 labeling pattern demonstrated granular appearance in comparison to that of vimentin. In addition, AGTR1 labeling was seen in ECs bodies and processes but without the honeycomb appearance that was observed with pan-cadherin labeling of these cells (figures 6 and 7 ). 
Stacks of image channels (red, green, golden yellow and blue) for the SMO, caudal part of median sulcus, ME and AP were generated as shown in figures 6, 7 and 8, which illustrate the expression of vimentin, pan-cadherin and AGTR1 markers. Basal processes of tanycyte-like cells were seen to extend to the deeper blood vessels in the SMO and ME but not in the caudal part of the median sulcus.

\section{Discussion}

In this study, we investigated morphological, structural and functional features of ECs at the SMO and compared it with those of tanycytes in the ME. Previous ultrastructural findings suggest the SMO region to be an undescribed CVO based on the general morphology of cells in the floor of the $4^{\text {th }}$ ventricle which is similar to tanycytes that are found in other CVOs. These morphological features were clearly demonstrated by the supra-ependymal cells over non-ciliated ependyma, the existence of desmosomes, apical fibrils, dense microvillus bouquets and active pinocytotic vesicles (Collins, 1989). Works on raphe dendrite bundle illustrated the presence of tanycytes on the midline floor of the $4^{\text {th }}$ ventricle using Golgi-cox and electron microscopic examination (Cummings and Felten, 1979). Other studies established vimentin to be a valid marker for detecting basal processes of tanycytes (Kirik et al., 2014). We investigated ECs in the SMO region utilizing vimentin immunohistochemical labeling which showed basal processes bridging to the deeply located blood vessels, a characteristic feature reported in the CVOs where tanycytic basal processes can reach several hundred microns in length to contact regions in close association with capillaries and arterioles (Bolborea and Dale, 2013).

Studies on tanycytes, in particular subtypes $\beta_{1}$ and $\beta_{2}$ (Rodriguez et al., 2005, Williams et al., 2005), demonstrated adhesion junctions at the ventricular cell pole throughout the cell bodies, the basal processes and terminals. These adhesion junctions are necessary for the primary contact between tanycytes and endothelial cells of brain vessels. Also, they are involved in the formation of tight junctions since cadherin system is established now to be critical for well-organized tight junction morphology and function (Engelhard and Valyi-Nagy, 2006). In this study, we found that ECs population at the SMO demonstrated basal cell processes (an established feature of tanycytes), in addition, these cells carry pan-cadherin proteins (an established marker for adhesion junctions) between cell bodies in a cobblestone pattern as well as along their basal processes. These findings were validated through the comparison with the presence of adhesion junctions in two previously confirmed CVOs (ME and AP) (Johnson and Gross, 1993) implementing pan-cadherin as a marker (Rodriguez et al., 2005, Williams et al., 2005).

Detailed immunohistochemical and permeability studies confirmed differential spatial distribution of tight junction proteins in the hypothalamus (Mullier et al., 2010). Many authors have noted that in this region, ECs express the tight junction protein ZO1 as opposed to capillary endothelial cells (Petrov et al., 1994, Smith and Shine, 1992) which are fenestrated (Miyata, 2015), resulting in a shifted barrier from the vascular to the ventricular pole. In this study, we found ZO1 
protein expression in ECs of the SMO, similar to that expressed in the region of the ME, suggesting the presence of specialized population of ECs with barrier properties. These results bring to front the unique SMO feature as a CVO possessing junctional complexes between its ECs or tanycyte-like cell lining. These junctional complexes may resemble those found in regions of BBB, where they are critical for restricting vascular permeability (Morita et al., 2015) since brain homeostasis entails maintaining special barriers with the periphery. Such barriers are provided by tight junctions at brain microvessels endothelium in the BBB regions and choroid plexuses epithelium (Mullier et al., 2010). However, in the CVOs, capillaries are fenestrated (Ciofi et al., 2009) to permit the two-way exchange of information between the blood and brain, hence the terms "sensory" and "secretory" CVOs are introduced (Morita et al., 2015). Therefore, in order for the CVOs to be able to perform these functions while maintaining the internal environment, there is a displacement or transposition of the barrier assets from the vascular to the ventricular pole where specialized ECs (the tanycytes) have well-defined tight junctions (Langlet et al., 2013). These tanycytes are a characteristic feature of all CVOs and their presence is mandatory to classify a region as a CVO (Langlet et al., 2013).

To our knowledge, none has elaborated on the presence of AGTR1 at the rostral region of the median sulcus. The findings in this study provide an evidence of the presence of AGTR1 at ECs of the SMO, a feature that is documented in other CVOs (Bregonzio et al., 2008, Walimbe et al., 2003). Localization of AGTR1 has been under extensive studies with the available data obtained by diverse methodology like radioligand binding, angiotensin receptor autoradiography, mRNA localization, local application of angiotensin II, electrophysiological studies, fos induction, or by immunereactivity; these methods led to the mapping of murine brain regarding AGTR1, that showed highest levels in the subfornical organ, ME, paraventricular nucleus, AP, and NTS (Premer et al., 2013). However, multiple studies found different levels of AGTR1 densities in many other locations of the brain (Mendelsohn et al., 1984). This might be attributed to the difference in methods of detection that have different detection standards. In addition, the use of immunohistochemical studies had been criticized previously due to some reports of poor specificity in commercial AGTR1 antibodies that are commonly used in published articles (Herrera et al., 2013, Benicky et al., 2012). Nevertheless, these reports on the specificity of AGTR1 markers can still be challenged with the accurate findings obtained from the knockdown or knockout animals used in such studies (Ito et al., 1995), in addition to the use of immunolabeling controls for each patch of the primary antibody used. Until such controversy is definitively solved, immunohistochemical studies will remain a complement to other methods of AGTR1 detection (Huang et al., 2016, Ishiguro et al., 2015, Mastropaolo et al., 2015, Zawada et al., 2015, Premer et al., 2013) and support the findings which hypothesize that the SMO is an overlooked CVO.

There are seven known CVOs (Horsburgh and Massoud, 2013) where microvessels lack barrier properties, giving these regions a unique role as "brain windows" that interact with variations of the internal environment (Mullier et al., 2010). It is interesting that AP is the only CVO in the $4^{\text {th }}$ ventricle, whereas the remaining six CVOs are located at the level of the $3^{\text {rd }}$ ventricle. This fact was challenged by Collin's findings (Collins, 1989) that were in accord with our results. The AP has fiber connections with several proximal nuclei like nucleus of tractus solitaries (NTS), nucleus ambiguous, 
mesencephalic nucleus of trigeminus and locus ceruleus (Vigh et al., 2004a). We suggest that the localization of some of these nuclei deep to the region of the SMO (NTS, nucleus ambiguous) or adjacently in a rostral direction (locus ceruleus) grants them a preferred site for non-synaptic signal transmission of the brain through its CSF-contacting neurons system (Vigh et al., 2004b). This "volume transmission" via extrasynaptic diffusion is still not a fully explored pathway (Feng et al., 2011). Our results highlight the SMO as a trafficking center in a strategic location for signal integration between brainstem nuclei and the rostrally located neuronal centers, forming one syncytium of CVOs bridged by the CSF.

\section{Conclusion}

This pilot study on the immunohistochemical features of ECS at the SMO sustained previous electron microscopic findings that suggest the SMO as a novel CVO. Detailed mapping of ECs, or tanycyte-like cells, properties at the SMO is yet to be performed to fully understand the function of this region.

\section{Acknowledgements}

Authors acknowledge the support and generous participation of University of Tasmania, Faculty of Health, School of Medicine - Australia, and Al-Nahrain University, College of Medicine - Iraq.

Special thanks to Mr. Steven Weston, former Lab Manager, Breathe-Well CRE, School of Medicine, University of Tasmania, for his kind technical advice and substantial assistance.

\section{References:}

BANCROFT, J. D. L., C. 2013. The Hematoxylins and Eosin. In: SUVARNA, S. K., LAYTON, C., \& BANCROFT, J. D. (ed.) Bancroft's Theory and Practice of Histological Techniques. 7th ed. China: Churchill Livingstone.

BENARROCH, E. E. 2011. Circumventricular organs: receptive and homeostatic functions and clinical implications. Neurology, 77, 1198-204.

BENICKY, J., HAFKO, R., SANCHEZ-LEMUS, E., AGUILERA, G. \& SAAVEDRA, J. M. 2012. Six commercially available angiotensin II AT1 receptor antibodies are non-specific. Cell Mol Neurobiol, 32, 1353-65.

BOLBOREA, M. \& DALE, N. 2013. Hypothalamic tanycytes: potential roles in the control of feeding and energy balance. Trends Neurosci, 36, 91-100.

BREGONZIO, C., SELTZER, A., ARMANDO, I., PAVEL, J. \& SAAVEDRA, J. M. 2008. Angiotensin II AT(1) receptor blockade selectively enhances brain AT(2) receptor expression, and abolishes the cold-restraint stress-induced increase in tyrosine hydroxylase mRNA in the locus coeruleus of spontaneously hypertensive rats. Stress, 11, 457-66.

CAMPESE, V. M., YE, S., TRUONG, R. H. \& GAMBURD, M. 2000. Losartan reduces sympathetic nerve outflow from the brain of rats with chronic renal failure. J Renin Angiotensin Aldosterone Syst, 1, 202-8.

CIOFI, P., GARRET, M., LAPIROT, O., LAFON, P., LOYENS, A., PREVOT, V. \& LEVINE, J. E. 2009. Brain-endocrine interactions: a microvascular route in the mediobasal hypothalamus. Endocrinology, 150, 5509-19. 
COLLINS, P. 1989. The sulcus medianus organ in the fourth cerebral ventricle of the rabbit: a previously undescribed circumventricular organ. J Anat, 162, 185-93.

COTTRELL, G. T. \& FERGUSON, A. V. 2004. Sensory circumventricular organs: central roles in integrated autonomic regulation. Regul Pept, 117, 11-23.

CUMMINGS, J. P. \& FELTEN, D. L. 1979. A raphe dendrite bundle in the rabbit medulla. J Comp Neurol, 183, 1-23.

DUVERNOY, H. M. \& RISOLD, P. Y. 2007. The circumventricular organs: an atlas of comparative anatomy and vascularization. Brain Res Rev, 56, 119-47.

ENGELHARD, H. H. \& VALYI-NAGY, T. 2006. Biology of the Blood-Brain and "Blood-Brain Tumor" Barriers. In: NEWTON, H. B. (ed.) Handbook of Brain Tumor Chemotherapy. 1st ed. USA: Academic Press.

FENG, C. Y., WIGGINS, L. M. \& VON BARTHELD, C. S. 2011. The locus ceruleus responds to signaling molecules obtained from the CSF by transfer through tanycytes. J Neurosci, 31, 9147-58.

FRY, M. \& FERGUSON, A. V. 2007. The sensory circumventricular organs: brain targets for circulating signals controlling ingestive behavior. Physiol Behav, 91, 413-23.

GANONG, W. F. 2000. Circumventricular organs: definition and role in the regulation of endocrine and autonomic function. Clin Exp Pharmacol Physiol, 27, 422-7.

HERRERA, M., SPARKS, M. A., ALFONSO-PECCHIO, A. R., HARRISON-BERNARD, L. M. \& COFFMAN, T. M. 2013. Lack of specificity of commercial antibodies leads to misidentification of angiotensin type 1 receptor protein. Hypertension, 61, 253-8.

HINDMARCH, C. C., FRY, M., SMITH, P. M., YAO, S. T., HAZELL, G. G., LOLAIT, S. J., PATON, J. F., FERGUSON, A. V. \& MURPHY, D. 2011. The transcriptome of the medullary area postrema: the thirsty rat, the hungry rat and the hypertensive rat. Exp Physiol, 96, 495-504.

HORSBURGH, A. \& MASSOUD, T. F. 2013. The circumventricular organs of the brain: conspicuity on clinical 3T MRI and a review of functional anatomy. Surg Radiol Anat, 35, 343-9.

HUANG, Z., OHNO, N., TERADA, N., SAITOH, Y., CHEN, J. \& OHNO, S. 2016. Immunohistochemical Detection of Angiotensin II Receptors in Mouse Cerebellum. In Vivo Cryotechnique in Biomedical Research and Application for Bioimaging of Living Animal Organs. Springer.

ISHIGURO, S., YOSHIMURA, K., TSUNEDOMI, R., OKA, M., TAKAO, S., INUI, M., KAWABATA, A., WALL, T., MAGAFA, V. \& CORDOPATIS, P. 2015. Involvement of angiotensin II type 2 receptor (AT2R) signaling in human pancreatic ductal adenocarcinoma (PDAC): a novel AT2R agonist effectively attenuates growth of PDAC grafts in mice. Cancer biology \& therapy, 16, 307-316.

ITO, M., OLIVERIO, M. I., MANNON, P. J., BEST, C. F., MAEDA, N., SMITHIES, O. \& COFFMAN, T. M. 1995. Regulation of blood pressure by the type $1 \mathrm{~A}$ angiotensin II receptor gene. Proc Natl Acad Sci U S A, 92, 3521-5.

JOHNSON, A. K. \& GROSS, P. M. 1993. Sensory circumventricular organs and brain homeostatic pathways. FASEB J, 7, 678-86.

JOLY, J. S., OSORIO, J., ALUNNI, A., AUGER, H., KANO, S. \& RETAUX, S. 2007. Windows of the brain: towards a developmental biology of circumventricular and other neurohemal organs. Semin Cell Dev Biol, 18, 512-24.

KIRIK, O. V., NAZARENKOVA, A. V. \& SUFIYEVA, D. A. 2014. [Three-dimensional visualization of the brain ependyma and tanycytes]. Morfologiia, 145, 63-6.

KUMAR, G. \& RUDBECK, L. 2009. Education Guide: Immunohistochemical (IHC) Staining Methods, USA, Dako North America.

LANGLET, F. 2014. Tanycytes: a gateway to the metabolic hypothalamus. J Neuroendocrinol, 26, 753-60.

LANGLET, F., MULLIER, A., BOURET, S. G., PREVOT, V. \& DEHOUCK, B. 2013. Tanycyte-like cells form a bloodcerebrospinal fluid barrier in the circumventricular organs of the mouse brain. J Comp Neurol, 521, 3389-405.

LINDEMANN, B. \& LEONHARDT, H. 1973. [Supraependymal neurites, mitochondrial bulbs and glia cells in the caudal segment of the floor of the 4th ventricle]. Z Zellforsch Mikrosk Anat, 140, 401-12. 
MACOVA, M., PAVEL, J. \& SAAVEDRA, J. M. 2009. A peripherally administered, centrally acting angiotensin II AT2 antagonist selectively increases brain AT1 receptors and decreases brain tyrosine hydroxylase transcription, pituitary vasopressin and ACTH. Brain Res, 1250, 130-40.

MASTROPAOLO, M., ZIZZO, M., AUTERI, M., CALDARA, G., LIOTTA, R., MULÈ, F. \& SERIO, R. 2015. Activation of angiotensin II type 1 receptors and contractile activity in human sigmoid colon in vitro. Acta Physiologica, 215, 37-45.

MENDELSOHN, F. A., QUIRION, R., SAAVEDRA, J. M., AGUILERA, G. \& CATT, K. J. 1984. Autoradiographic localization of angiotensin II receptors in rat brain. Proc Natl Acad Sci U S A, 81, 1575-9.

MIRZADEH, Z., KUSNE, Y., DURAN-MORENO, M., CABRALES, E., GIL-PEROTIN, S., ORTIZ, C., CHEN, B., GARCIAVERDUGO, J. M., SANAI, N. \& ALVAREZ-BUYLLA, A. 2017. Bi- and uniciliated ependymal cells define continuous floor-plate-derived tanycytic territories. Nat Commun, 8, 13759.

MIYATA, S. 2015. New aspects in fenestrated capillary and tissue dynamics in the sensory circumventricular organs of adult brains. Front Neurosci, 9, 390.

MORITA, S., FURUBE, E., MANNARI, T., OKUDA, H., TATSUMI, K., WANAKA, A. \& MIYATA, S. 2015. Heterogeneous vascular permeability and alternative diffusion barrier in sensory circumventricular organs of adult mouse brain. Cell Tissue Res.

MORITA, S. \& MIYATA, S. 2012. Different vascular permeability between the sensory and secretory circumventricular organs of adult mouse brain. Cell Tissue Res, 349, 589-603.

MULLIER, A., BOURET, S. G., PREVOT, V. \& DEHOUCK, B. 2010. Differential distribution of tight junction proteins suggests a role for tanycytes in blood-hypothalamus barrier regulation in the adult mouse brain. J Comp Neurol, 518, 943-62.

PETROV, T., HOWARTH, A. G., KRUKOFF, T. L. \& STEVENSON, B. R. 1994. Distribution of the tight junctionassociated protein ZO-1 in circumventricular organs of the CNS. Brain Res Mol Brain Res, 21, 235-46.

PREMER, C., LAMONDIN, C., MITZEY, A., SPETH, R. C. \& BROWNFIELD, M. S. 2013. Immunohistochemical Localization of AT1a, AT1b, and AT2 Angiotensin II Receptor Subtypes in the Rat Adrenal, Pituitary, and Brain with a Perspective Commentary. Int J Hypertens, 2013, 175428.

RIZZOTI, K. \& LOVELL-BADGE, R. 2016. Pivotal role of median eminence tanycytes for hypothalamic function and neurogenesis. Mol Cell Endocrinol.

ROdRIGUEZ, E. M., BLAZQUEZ, J. L., PASTOR, F. E., PELAEZ, B., PENA, P., PERUZZO, B. \& AMAT, P. 2005. Hypothalamic tanycytes: a key component of brain-endocrine interaction. Int Rev Cytol, 247, 89-164.

ROTH, J., HARRE, E. M., RUMMEL, C., GERSTBERGER, R. \& HUBSCHLE, T. 2004. Signaling the brain in systemic inflammation: role of sensory circumventricular organs. Front Biosci, 9, 290-300.

SHI, S. R., LIU, C. \& TAYLOR, C. R. 2007. Standardization of immunohistochemistry for formalin-fixed, paraffin-embedded tissue sections based on the antigen-retrieval technique: from experiments to hypothesis. J Histochem Cytochem, 55, 105-9.

SMITH, G. M. \& SHINE, H. D. 1992. Immunofluorescent labeling of tight junctions in the rat brain and spinal cord. Int J Dev Neurosci, 10, 387-92.

VIGH, B., MANZANO E SILVA, M. J., FRANK, C. L., DAVID, C., CZIROK, S. J., VINCZE, C., RACZ, G., LUKATS, A. \& SZEL, A. 2004a. The Circumventricular Organs of the Brain: Do They Represent a Cerebrospinal FluidDependent Regulatory System? Med Hypotheses Res, 1, 77-100.

VIGH, B., MANZANO E SILVA, M. J., FRANK, C. L., VINCZE, C., CZIROK, S. J., SZABO, A., LUKATS, A. \& SZEL, A. 2004b. The system of cerebrospinal fluid-contacting neurons. Its supposed role in the nonsynaptic signal transmission of the brain. Histol Histopathol, 19, 607-28.

WALIMBE, V., ZAGRODSKY, V., RAJA, S., JABER, W. A., DIFILIPPO, F. P., GARCIA, M. J., BRUNKEN, R. C., THOMAS, J. D. \& SHEKHAR, R. 2003. Mutual information-based multimodality registration of cardiac ultrasound and SPECT images: a preliminary investigation. Int J Cardiovasc Imaging, 19, 483-94.

WILLIAMS, M. J., LOWRIE, M. B., BENNETT, J. P., FIRTH, J. A. \& CLARK, P. 2005. Cadherin-10 is a novel bloodbrain barrier adhesion molecule in human and mouse. Brain Res, 1058, 62-72.

ZAWADA, W., MRAK, R. E., BIEDERMANN, J., PALMER, Q. D., GENTLEMAN, S. M., ABOUD, O. \& GRIFFIN, W. S. T. 2015. Loss of angiotensin II receptor expression in dopamine neurons in Parkinson's disease 
correlates with pathological progression and is accompanied by increases in Nox4-and 8-OH guanosine-related nucleic acid oxidation and caspase-3 activation. Acta Neuropathol Commun, 3, 9. 
Figure 1. Diagrammatic summary of barriers relationships between various brain compartments. Tight junctions of brain capillaries endothelium form the blood-brain barrier, and similar junctional complexes in the choroid plexus epithelium make the barrier between plexus capillaries and the cerebrospinal fluid (CSF). Tanycytes at the sulcus medianus organum (SMO) integrate between the proposed fenestrated capillaries and the neurons in this region, and form the necessary barrier for leaked substances from these capillaries and the nearby brain ventricles.
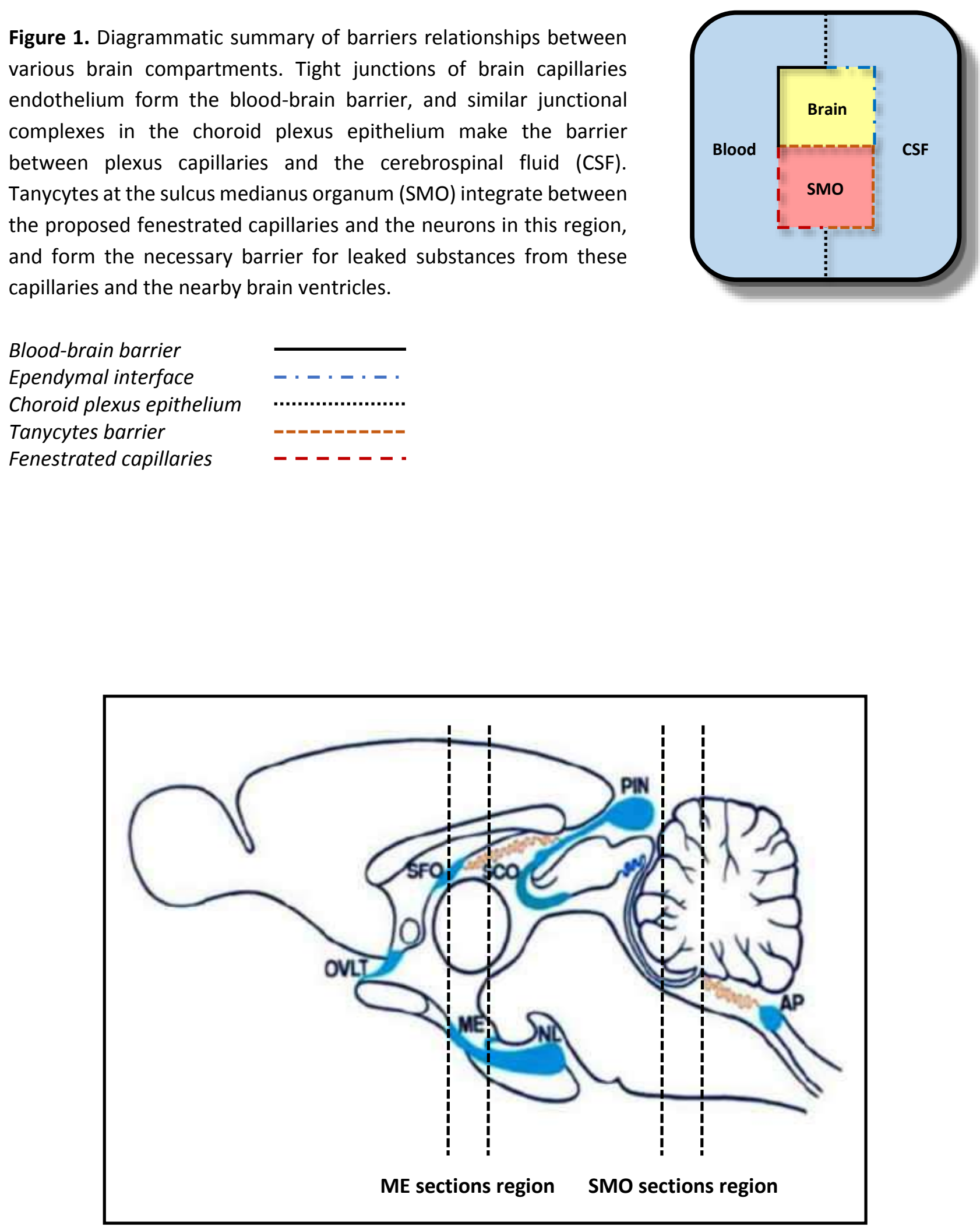

Figure 2. Schematic drawing of a mid-sagittal section through the rat brain. Areas of CVOs are shown in blue color ( $\mathrm{AP}=$ area postrema; $\mathrm{ME}=$ median eminence; $\mathrm{NL}$ = neural lobe of the pituitary; $\mathrm{OVLT}$ = vascular organ of the lamina terminalis; PIN = pineal organ; SCO = subcomissural organ; SFO = subfornical organ). Location of specimens trimming are indicated by the dotted lines. Modified from (Roth et al., 2004). 


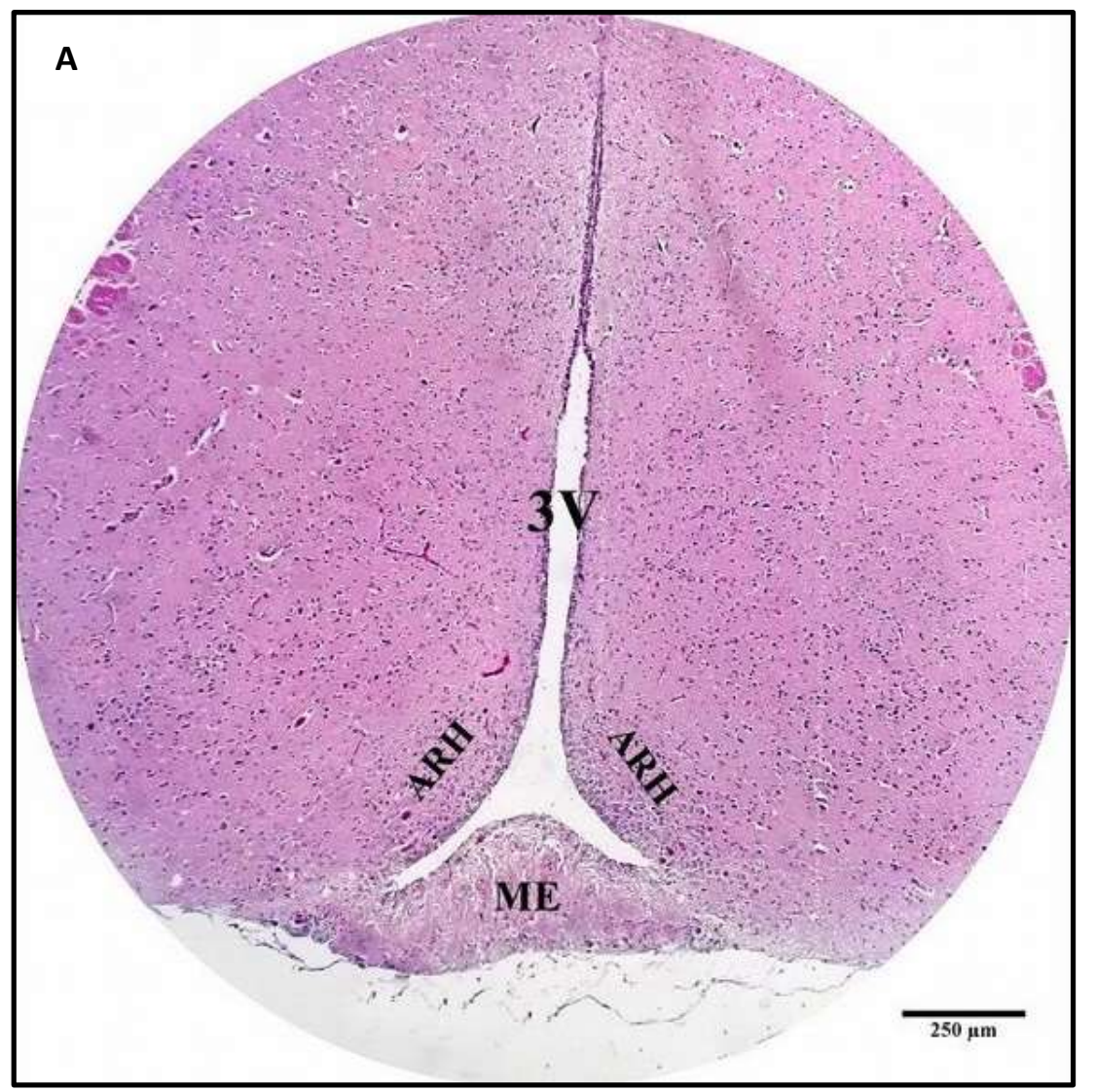

Figure 3. Coronal sections of rat brain at the region of ME. Ependymal lining of $3^{\text {rd }}$ ventricle consists of a single layer of cuboidal or columnar cells (arrows). H. \& E. stain. (A) 100X. (B) 400X. 3V: $3^{\text {rd }}$ ventricle. ME: median eminence. ARH: arcuate hypothalamic nucleus.

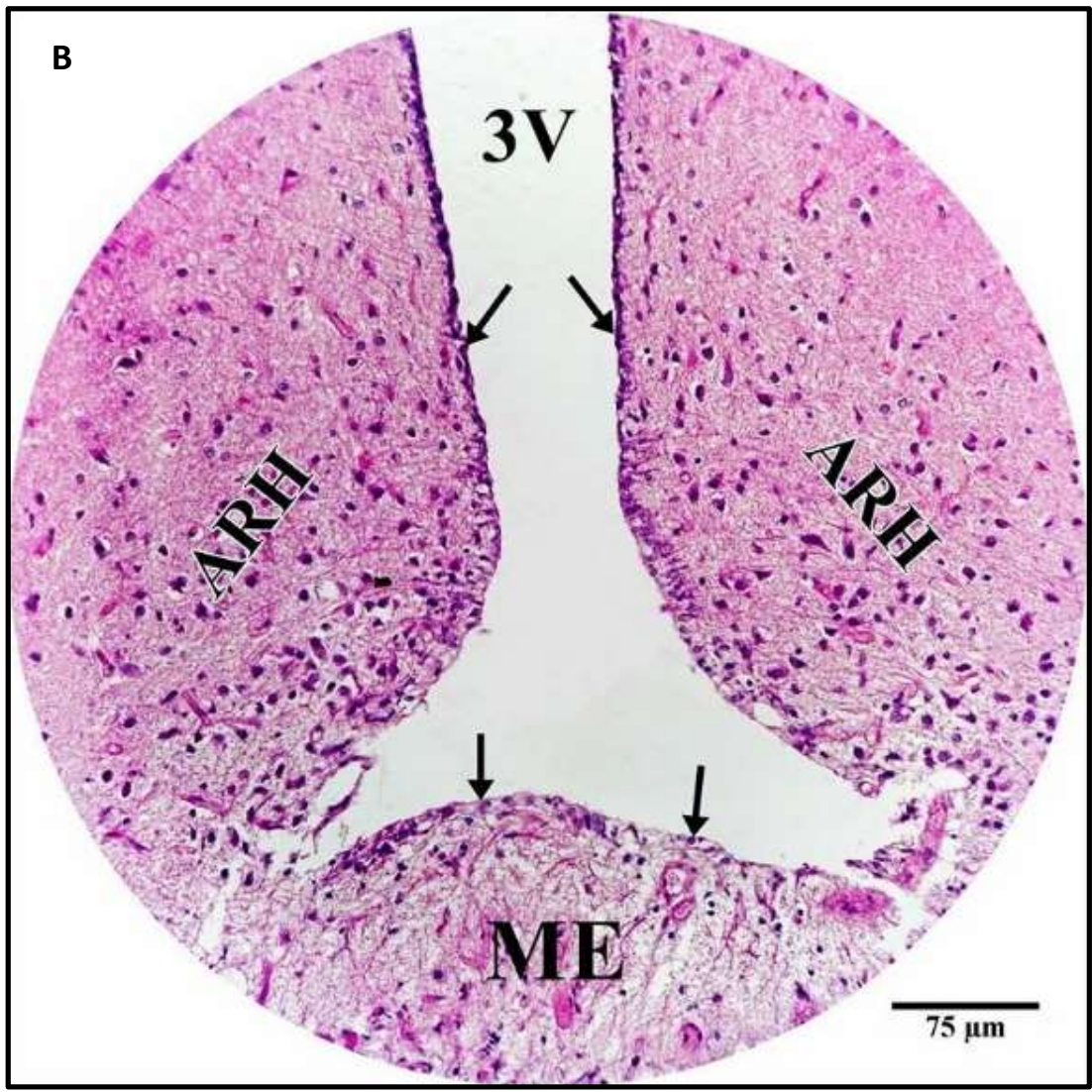




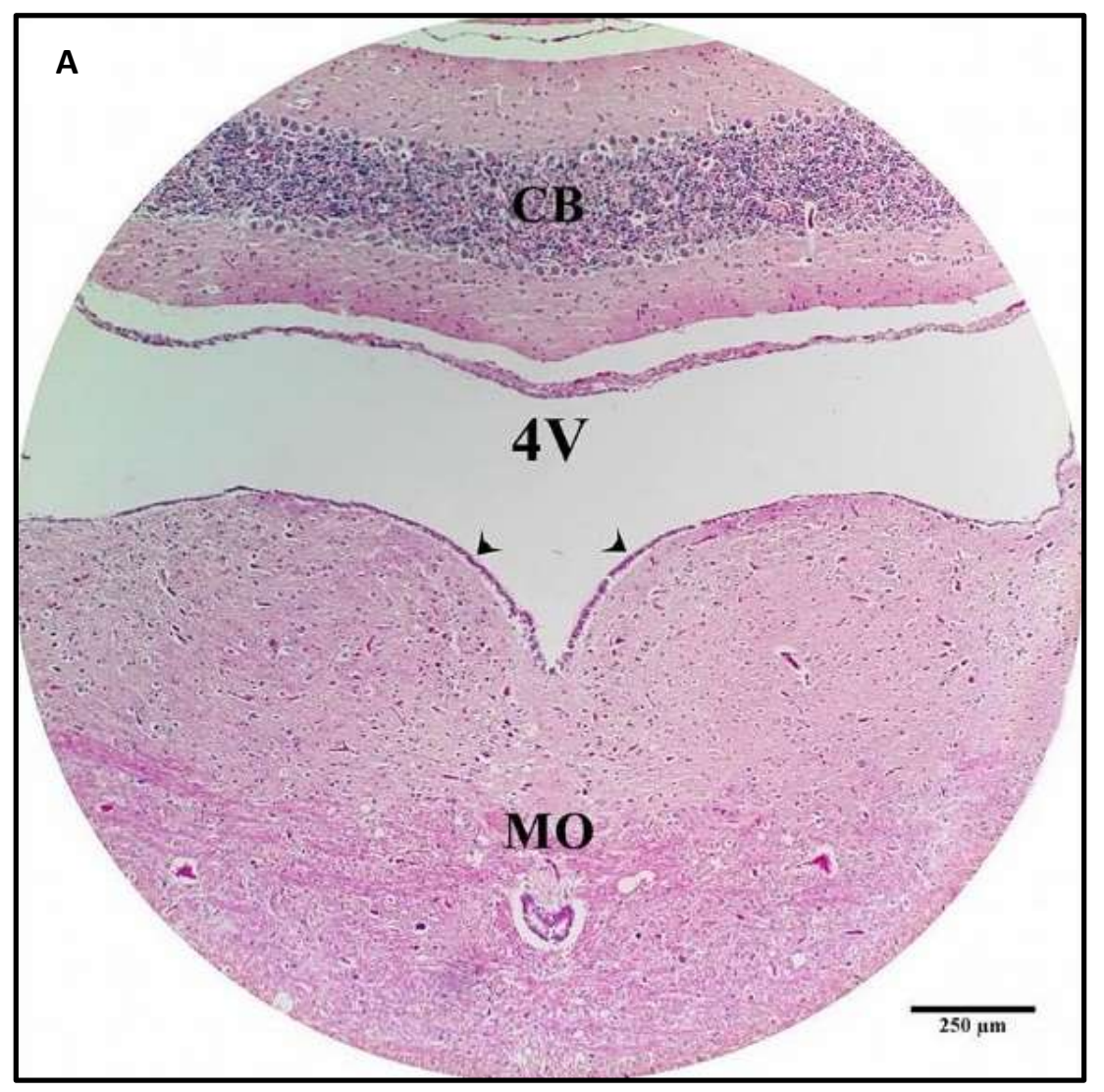

Figure 4. Coronal sections of rat brainstem at the region of SMO. Ependymal lining of $4^{\text {th }}$ ventricle consists of a single layer of cuboidal or columnar cells (arrow heads in A) except at the deepest part of the median sulcus of the SMO (arrows in B) where they are arranged in 2-3 layers. These cells ciliated (arrow heads in B). H. \& E. stain. (A) 100X. (B) 1250X. 4V: $4^{\text {th }}$ ventricle. $\mathrm{CB}$ : cerebellum. $\mathrm{MO}$ : medulla oblongata.

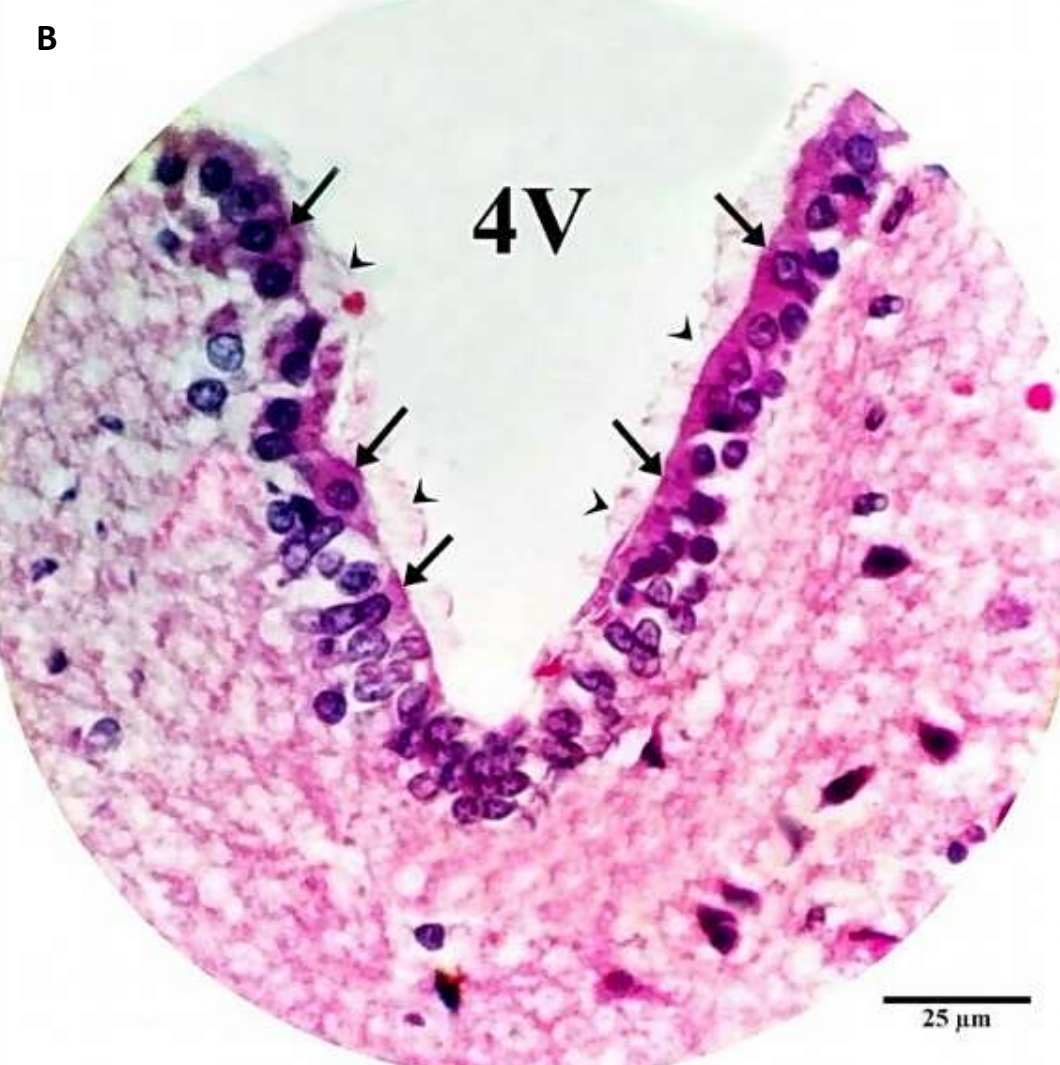



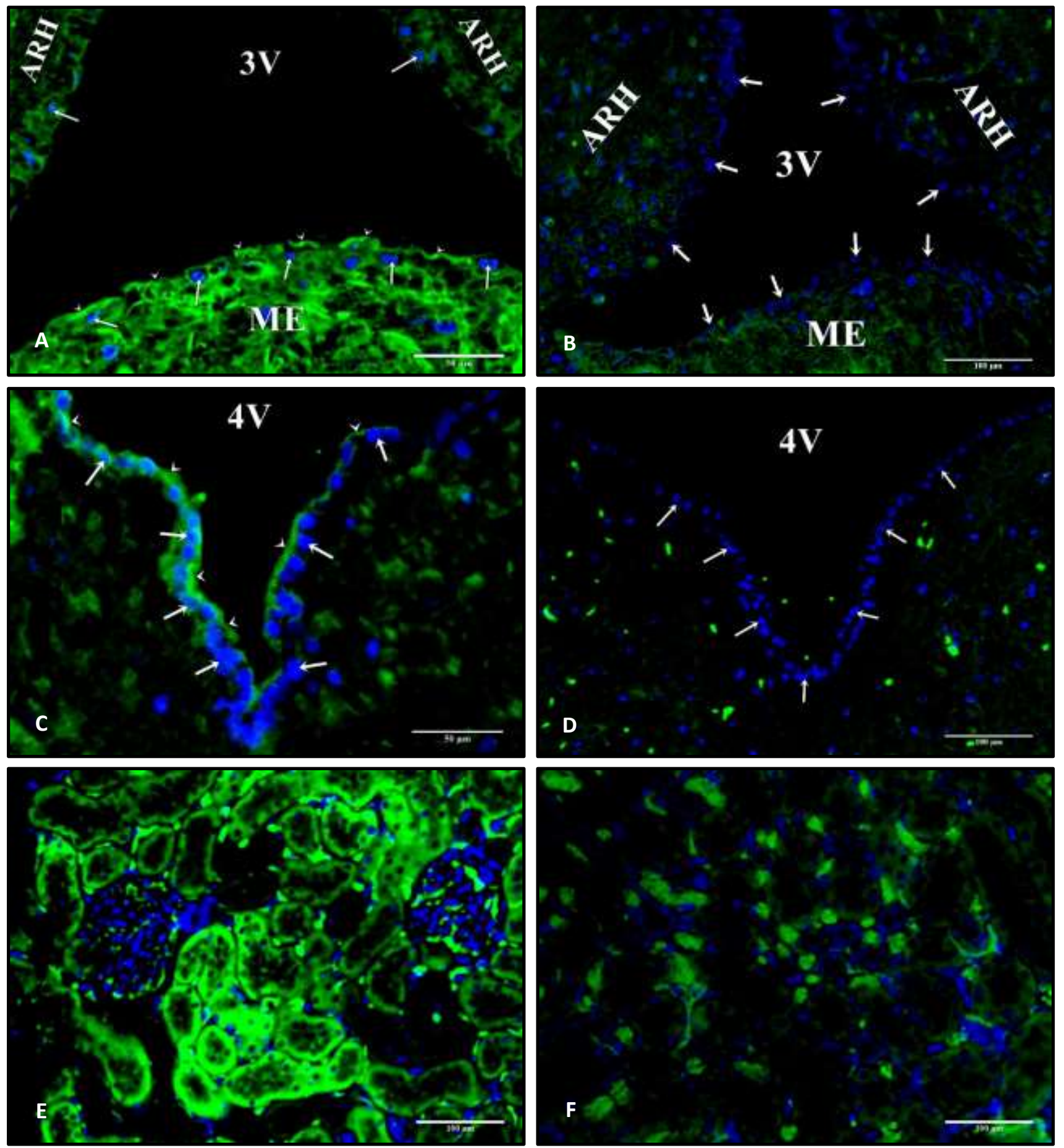

Figure 5. Immunofluorescence labeling of $Z O 1$ in the ME and SMO of rat brain. Tight junctions show bright green fluorescence (arrows heads in $A$ and $C$ ) between tanycyte-like cells in the ME ( $A$ and $B$ ) and SMO (C and $D$ ) that has blue fluorescence (arrows in $A-D$ ). Negative controls are seen in $A(S M O)$ and $C$ (ME). Positive and negative controls from kidney sections are shown in $E$ and $F$, respectively. 400X. ME: median eminence. ARH: arcuate hypothalamic nucleus. $3 \mathrm{~V}$ : $3^{\text {rd }}$ ventricle. $4 \mathrm{~V}: 4^{\text {th }}$ ventricle. 

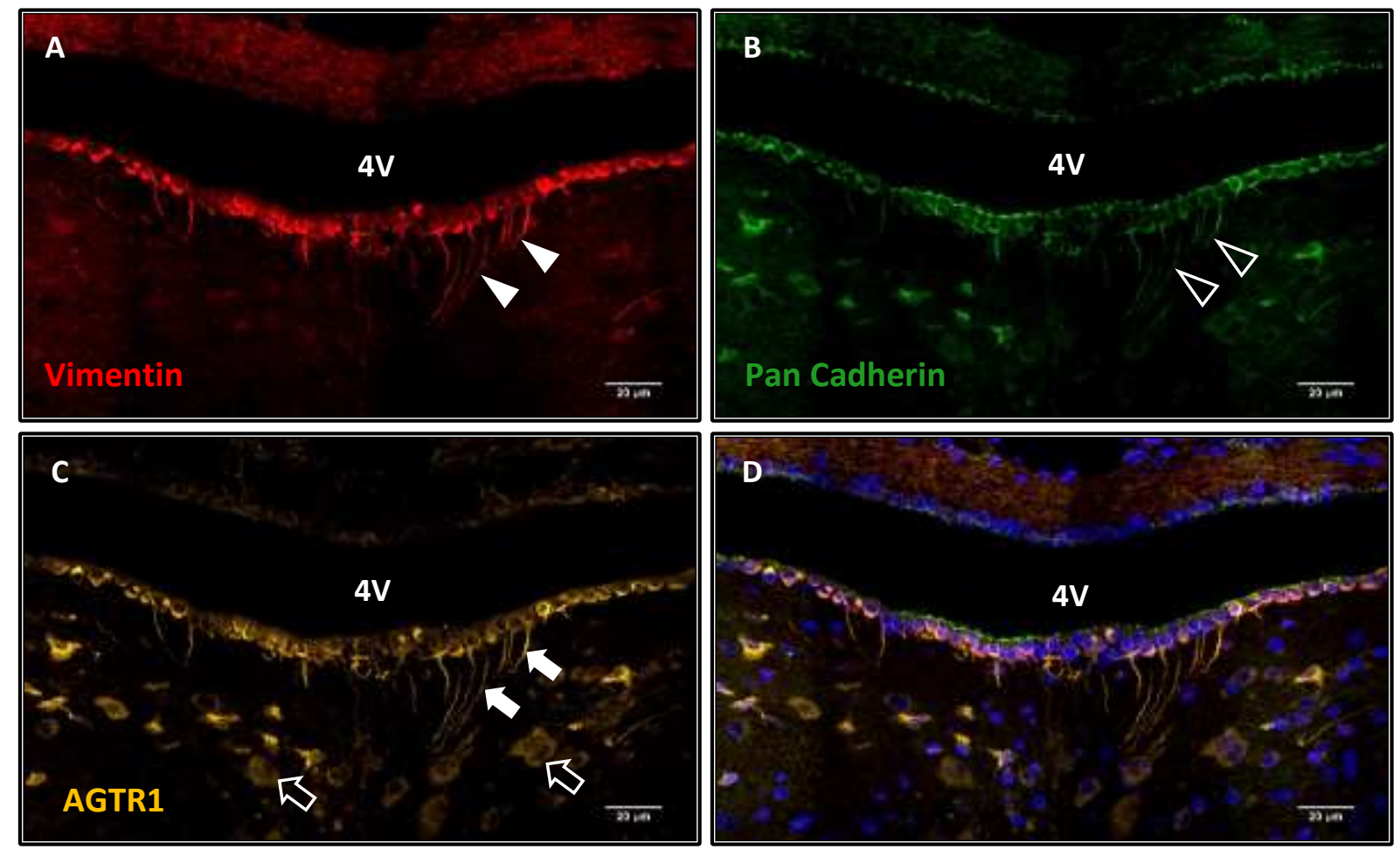

Figure 6. Immunofluorescence labeling of vimentin, pan cadherin and AGTR1 in coronal sections of rat brain at the region of SMO. (A) Vimentin-labeled basal processes of tanycyte-like cells (arrow heads) extend deep in the parenchyma. (B) Tanycyte-like cells display pan-cadherin labeling on their processes (empty arrow heads) as well as a honeycomb pattern at their cell surfaces. (C) AGTR1 labeling of tanycytelike cell bodies and processes (arrows). The deep parenchymal cells also demonstrate AGTR1 labeling but with a dotted appearance (empty arrows). Additionally, ependyma of the dorsal aspect of the fourth ventricle (4V) showed weak AGTR1 labeling. Nuclei were labeled with DAPI (blue). Scale bar $=20 \mu \mathrm{m}$ 

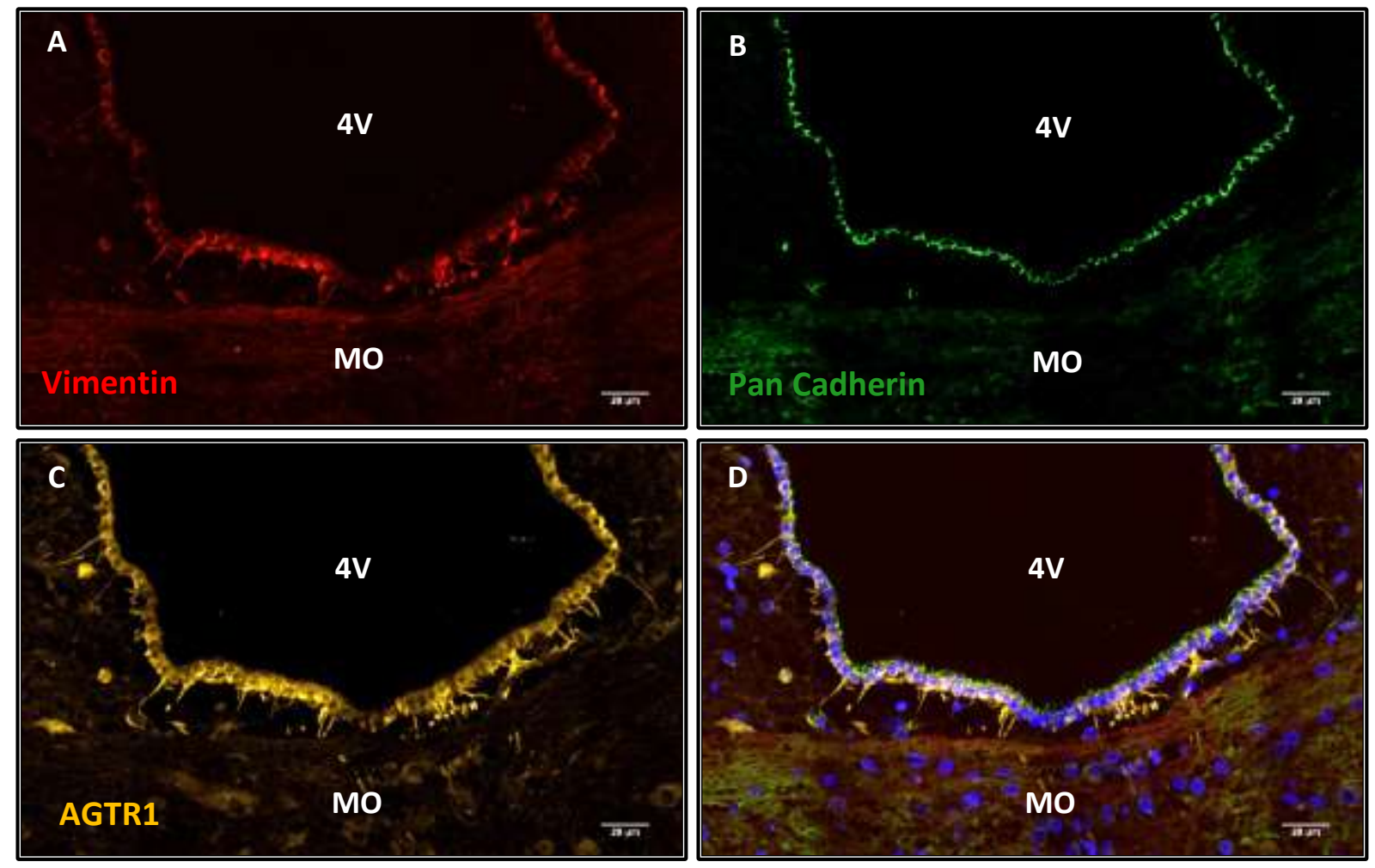

Figure 7. Immunofluorescence labeling of pan cadherin (green) at the free surface of vimentin (red)-AGTR1 (golden yellow) co-labeled tanycyte-like cells in coronal sections of rat brain at the region of caudal part of the median sulcus. Sections were also labeled with DAPI nuclear staining (blue). Deep parenchymal extension of tanycyte-like cells basal processes was less than that observed in the region of SMO. Cells labeled with AGTR1 were less than those seen in the SMO. 4V: fourth ventricle. Scale bar $=20 \mu \mathrm{m}$ 

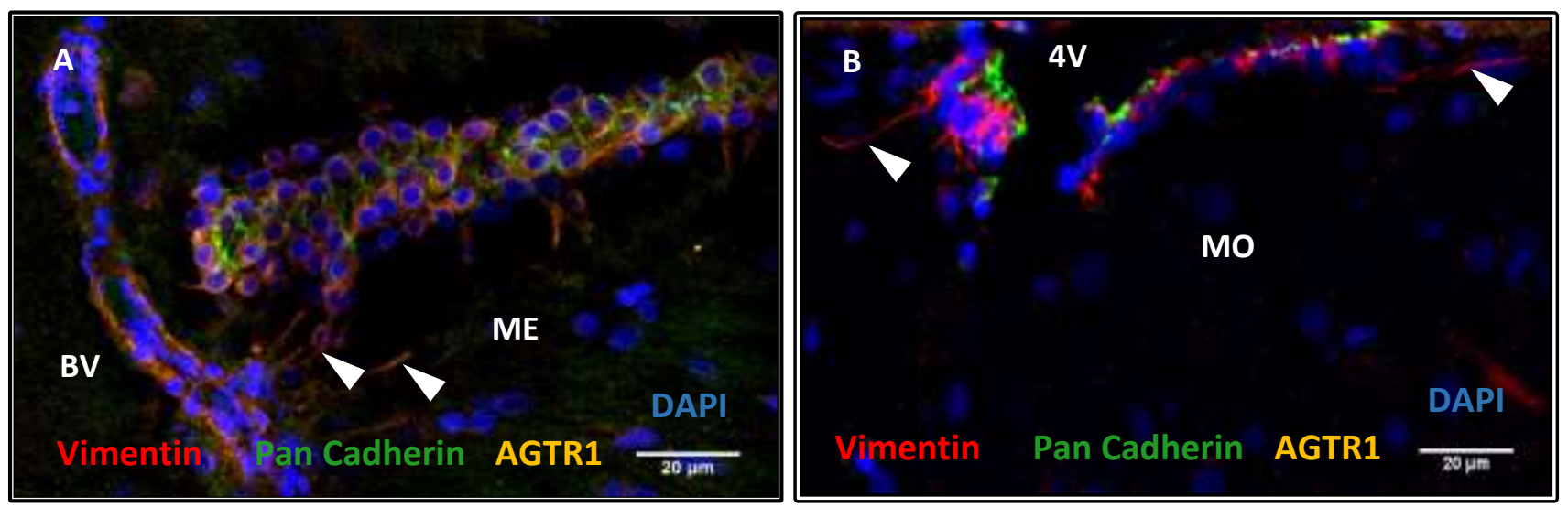

Figure 8. Photomicrographs demonstrating vimentin (red) and pan cadherin (green) labeled tanycyte-like cells in coronal sections of rat brain ME (A) and AP (B) with DAPI nuclear staining (blue). Tanycyte-like cell processes (arrow heads) reach adjacent blood vessels (BV) in the ME and pass in the parenchyma of the AP. Pan cadherin labeling gives a honeycomb appearance between tanycyte-like cells surfaces. 4V: fourth ventricle. MO: Medulla Oblongata. Scale bar $=20 \mu \mathrm{m}$ 